\title{
Rhetorical divergence; Real convergence? The economic policy debate in the 2002 French presidential and legislative elections
}

David Howarth, University of Edinburgh

This is a preliminary and unpublished version of the following book chapter: 'The Economic Policy Debate in the 2002 elections', in John Gaffney, ed., The 2002 French Presidential and Legislative Elections, Ashgate, 2004, pp. 200-221.

This chapter explores the reasons why, despite considerable convergence in the economic policy preferences and policies of the mainstream Left (principally Socialist Party) and Right, economic policy remained a major subject of debate during the 2002 election campaigns. Convergence had taken place thanks to the relatively successful pursuit by the Jospin Government of moderately rigorous policies and a cautious liberalisation over the previous five years which corresponded to the longest period of strong economic growth (1998 to 2001) since the late 1980s. The 2002 elections reflected the now well-established trend of an incumbent Socialist leadership to lean towards moderation on economic policies (as in 1986 and 1993). Furthermore, not constrained by any joint election manifesto with other parties of the Left, the Socialists demonstrated much greater moderation on economic policy than in the 1997 legislative elections, with the party's modernising wing firmly in control of the preparation of the 
Jospin campaign platform. Jospin and the Socialists refused to make any grand economic gestures to placate left-wing sentiments, promising no major cuts to income and corporate tax rates and, unlike 1997, refusing to advocate any questioning of the EU macro-economic policy constraints to which the Plural-Left government had committed itself. At the same time, fearing the loss of votes to the smaller parties of the Left, Jospin and the Socialists avoided advocating any policies that could be interpreted in terms of 'liberalisation'.

Despite the economic slowdown since 2001, the state of the economy did not provide fertile ground for President Chirac and the political opposition in the context of the electoral partisan debate. Issues raised by Chirac and the UMP indicated, however, that the mainstream Right was willing to move in a cautiously liberal direction in the context of electoral politics: major cuts to income and corporate taxes which became - along with tackling crime - the most vaunted election promise of Chirac's campaign and that of the UMP; relaxing the application of the 35 hour week policy (but not scrapping it) and introducing new schemes to encourage individual savings for retirement (which Chirac even dared to label 'fonds de pension à la française'). However, at the same time, Chirac played the rebel on economic policy, challenging the constraints of the Euro-zone's Stability 
and Growth Pact especially given that these constraints made the fulfilment of his promises on tax cuts and government spending unrealistic.

After a brief overview of the economic policy of the Jospin-led Government, this chapter explores the leading candidates' policy positions on the five major economic issues of the election campaign: tax; government spending and respecting the Stability Pact deficit rules; the 35 hour week and employment policy more generally; pensions reform and the privatisation of the remaining state owned utilities. This chapter concludes by demonstrating the failure of the two leading candidates — and most of the other candidates — and their parties to spell out a coherent economic agenda that delineated the desirable role of the state in relation to the market economy in the Twenty-first century.

It should be noted that the policy positions of the presidential candidates on economic matters had considerable significance in terms of setting the tone for their party's campaign positions. Few new economic policy ideas were presented by the parties in the campaign for the legislative elections following the second ballot of the presidential elections. Policy positions during the legislative campaign reiterated policies presented by the presidential candidates and their teams and focused upon President Chirac's own promises and the ability of the UMP government to carry them out and 
the reiteration of presidential candidate policies. For this reason, most of the analysis presented in this chapter focuses upon the policy positions and debates of the presidential candidates prior to the first ballot of the presidential elections. At the same time, it is recognised that the policy positions of the parties occasionally diverged from those of the leader. For example, the Socialist Party campaign document, prepared by Martine Aubry, better reflected the views of the party's left, while Jospin's platform was prepared entirely by the 'modernising wing'.

\section{The Jospin Government's economic policies}

The major lines of the economic policy pursued by the Jospin Government can be summarised as follows: privatisation, controls on state spending, the maintenance of high corporate and personal income taxes despite some cuts from 2000, and the 35 hour week - the major legitimising policy for a government trying to prove its left-wing credentials - to be applied to all companies by 2002. ${ }^{1}$ The privatisation and budget cutting policies of the Plural Left Government were made necessary to enable France to participate in Stage Three of EMU. However, even without EMU, the privatisation of state owned companies and banks was being pushed by the 'modernising', 'social-liberal' wing of the Socialist Party, led by Finance Minister Laurent 
Fabius and the former finance minister, Dominique Strauss-Kahn (commonly known as DSK). At the June 1997 European Council in Amsterdam, the newly elected Jospin Government confirmed the Juppé government's commitment to the Stability and Growth Pact. Over the next five years, the Jospin Government succeeded in privatisating more state assets, in terms of revenue, than the three previous conservative governments combined (Chirac, 1986-88; Balladur, 1993-95; Juppé, 199597); this despite the presence of Communist members and various other professed opponents of capitalism within the governing coalition.

In 1997, the Jospin Government agreed to its Broad Medium Term Economic Policy Guidelines (required by the Maastricht Treaty and the Stability Pact) which committed it to balancing the budget by 2002 (later pushed back to 2004). Despite election promises in 1997 to pursue a more 'activist' budgetary strategy and end budget cuts and the initial freeze of the post-electoral period, the Plural Left succeeded in making some minor cuts to state spending, principally through defence spending and the partial replacement of retiring staff. With one of the largest public administrations in Europe in terms of percentage of total jobs, cuts to staff numbers had been widely recommended. The Picq report of 1994 established the goal of replacing only one in three civil servants retiring from the administration in 
order to reduce the total number of staff to the 1980 level: a 15 per cent cut. In 1997, a secret reform written by two Financial Inspectors on overemployment (waste and inefficiency) in the public sector was suppressed but leaked to the Canard Enchaîné, weekly newspaper. The Balladur and Juppé governments postponed cuts given record high levels of unemployment, and the strong and militant trade-union presence in the public sector, led by Force Ouvrière. Under the Plural-Left government, the short-lived Finance Minister Christian Sautter even failed in his efforts to decrease the excessively large number of tax administrators in his own ministry due to Jospin's unwillingness to take on the unions and disenchant the Socialist electorate, found in disproportionately large numbers in the public sector. Sautter was replaced by the more politically astute former Prime Minister Laurent Fabius, who put all such cuts on hold. Relatively strong economic growth during its first three and a half years in office enabled the Jospin Government to delay more substantial, sustainable cuts until after the 2002 elections. On the right, just prior to the 1997 National Assembly elections, the UDF Minister of Finance Jean Arthuis promised to reduce personnel and even to change the budget ordinance of 1959 in order to prohibit a deficit on current expenditure. ${ }^{2}$ However, the Jospin Government continued to delay total staff cuts. It used staff replacement as a political device to demonstrate 
its commitment to job creation in the public sector, allied with temporary youth employment schemes, notably emplois jeunes.

The Jospin Government maintained the rhetoric of margin of manoeuvre in macroeconomic policy — vital for maintaining legitimacy on the left ${ }^{3}$ - initially promising an increase of 1 per cent in government expenditure (although in the government's December 1998 stabilisation plan this was qualified to cover the $2000-3$ period or slightly more than .3 per cent per year which would allow the lowering of the deficit in line with the 2004 balanced budget target), whereas the Juppé Government had sought an expenditure freeze and the RPR and UDF in opposition criticised the government for its inability to respect its balanced budget target. The unexpectedly large budget revenue in 2000 due to stronger than predicted economic growth — the 'cagnotte' — allowed increases in government spending and tax cuts. How much of each proved to be one of the most significant ideologically-driven economic debates within the Plural Left coalition and with the opposition. Jospin was prevented from using this money to further reduce the deficit by the Socialist left and the coalition partners, with the 2002 elections in view - thus setting up future governments for failure to meet the 2004 balanced budget aim. Elements of 
the Right, notably the UDF, challenged Plural-Left policy on this, with the proposal of a balanced budget law.

The Jospin Government maintained comparatively high corporate and income taxes (French corporate and income taxes are among the highest in the OECD) while taking the opportunity afforded by unexpectedly strong economic growth to make a limited number of small tax cuts. The 'cagnotte' provided some scope for action in this area. Fabius sought to prioritise income tax cuts - the first in 15 years was announced on 31 August 2000 — but was constrained by the Socialist left and the Plural Left coalition partners. These tax reductions benefited all income groups, but were designed ostensibly to benefit in particular the least well off. There were also moderate cuts in corporate tax rates, with the explicit aim of stimulating further economic growth which in turn would lower the deficit. Nearly all of the Right - from mainstream to extreme — pushed for much more significant cuts. Nonetheless, on 12 March 2002, INSEE published the public administration accounts for 2001, showing that the Jospin Government had succeeded in bringing the total tax burden to almost its 1996 level (44.9 per cent of GDP). ${ }^{4}$

Interventionist employment policies was the core area in which the Socialist-led government could demonstrate its commitment to maintaining 
the activist state-led approach of 'modern socialism'. 5 Employment creation is a particularly sensitive political matter for French governments given the high rate of unemployment, which reached 12.4 per cent in 1997. The relatively strong economic growth of the 1998-2000 period brought down the official unemployment rate to 8.7 per cent by 2001 (16.4 per cent for the under $25 \mathrm{~s}$ according to the government's May figures), for which the government was quick to credit its interventionist measures. There has been a marked difference between the Left and Right in France on employment policy. Governments of both the Left and Right had previously pursued voluntary measures to create jobs, temporarily reducing social charges and paying wages for companies which took on additional staff. ${ }^{6}$ The Left was more prone to creating special temporary government jobs, while there were elements in conservative governments that sought more orthodox solutions to lower unemployment: in $1993 / 4$, the Balladur Government sought to introduce a special minimum wage for young people (the contrat d'insertion professionnelle (CIP) known commonly as the SMIC jeune) which was withdrawn after violent protests. From 1997, the Plural Left Government opted for more interventionist measures: it established hundreds of thousands of special low-paid and temporary contracts for young people in the public sector (emplois-jeunes) and embraced the mandatory 35-hour 
week policy. The problematic logic behind the 35-hour week made the policy controversial, with the RPR and UDF and the MEDEF (patronat, the peak association for big business) resolutely opposed. The Jospin Government was also at the forefront of the development of a European employment policy but given British, German and Spanish opposition, the Employment chapter which was included in the Amsterdam Treaty at Jospin's insistence, only amounted to open co-ordination, information sharing and non-binding targets.

There was a strong element of party politics and ideological legitimation to this activism on employment policy. The Jospin Government sought to distinguish itself from its conservative predecessors while after their disastrous defeat in the 1993 legislative elections, the Socialists had also swung to the left. Within the party, the left-wing insisted upon more radical action on employment. In April 1997, despite strong opposition from the right-wing of the party (including the future prime minister Jospin and ministers of finance, Strauss-Kahn and Fabius) the Socialists voted for their interventionist policies as campaign policy. The Socialists were also encouraged to accept a more radical employment policy in the context of their joint elections manifesto with the Communists, the Greens and the MDC. Following its June 1997 election victory, the legitimising importance 
of the Plural Left's activist employment policy increased, given that the governing coalition soon substantially watered down or cancelled most of the more radical policies that it had promised in its elections manifesto. The 35-hour week policy was also manageable financially, in that it would not contribute to the public sector deficit. Government activism on employment was also aimed to address the gradual rise in the political action of the unemployed themselves and their supporters. Putting the policy into effect proved troublesome for the government even in its own left-wing constituency: the government initially promised that the drop in four hours from the work week would not coincide with a decline in pay but faced with the need to increase labour market flexibility and lower unemployment, the government allowed companies to freeze wages in the context of collective agreements with trade unions. Thus, as a legitimising device the 35 -hour week proved problematic.

President Chirac and politicians in the RPR and UDF criticised the Plural Left's policies as excessively interventionist and too restraining on companies. However, at the same time, few elements of the Right were willing to embrace a more far-reaching reform of the labour market that Anglo-American observers frequently recommended (notably a decrease in the minimum wage and increased flexibility with regard to hiring and 
firing). In fact, the 35 hour week policy was praised by some precisely because it resulted in 'increased flexibility' through the backdoor: allowing companies to freeze wages and increase the flexibility of working time through an annualisation of the 35 hour week.

\section{Partisan debate on the economy during the 2002 election campaigns}

Although economic growth had begun to decrease from mid-2001, given the relatively low rate of unemployment, the relatively buoyant consumer confidence and the apparent success of the Jospin government's liberalising reforms, the presidential candidates of the mainstream Right and their parties were not a strong position to challenge Jospin and the Plural Left on their management of the economy. Nor were the Green, Pôle Républicain and PCF presidential candidates and parties, given their collusion in the privatisations, budgetary restraint and the problematic employment policies of the Plural Left Government. Likewise, Jospin and Chirac sought to appeal to each other's voters in the centre ground of French politics and there was a marked blurring of their economic policy positions. Despite determined efforts by the two leading candidates to distinguish themselves from one another during the campaign, the policy implications of Jospin's 'modern socialism' ${ }^{17}$ and Chirac's mixed free market ideas alongside state 
interventionism — the President refused to label himself a 'liberal' despite advocating liberalising reforms and despite criticising the 'embedded socialism' in France - often appeared very much the same. The other candidates of the Left, presented their opposition to liberalising reforms; while candidates of the Right advocated further liberalisation. Only the unashamedly liberal Alain Madelin and the candidates of the Extreme Left and Right offered anything in the way of a dramatic departure from the status quo.

Nonetheless, despite the degree of convergence in economic policy, there were marked differences in the positions of the mainstream Left and Right candidates on economic policy issues during the presidential elections campaign which followed into the legislative election campaign. The two leading presidential candidate positions themselves to appeal to particular elements of French society: Jospin sought to appeal most to the voters of the moderate left, while Chirac presented himself his as more business and 'middle class' friendly, which should be compared to his opportunistic positioning during the 1995 presidential election campaign against economic orthodoxy and the constraints of the EMU project. In 1995, Chirac had to position himself in relation to his challenger on the Right, Edouard Balladur, who defended the financial orthodoxy of the Minc Report. Then Chirac 
presented himself as the candidate to heal the social divisions in French society, divisions aggravated by record unemployment levels and real interest rates. ${ }^{8}$ In 2002, the political and economic conditions did not require such a position. The principal economic policy differences between Jospin and Chirac and the Socialist Party / UMP camps had to do with tax and the European constraint. With regard to the former, Chirac and the UMP played the more traditional tune of the Right promising significant cuts to a tax-exhausted middle class. With regard to the latter, Chirac and the UMP took a more ambiguous line: accepting the need for budgetary restraint and accepting the desirability of the goal of balanced budgets while refusing to commit to the balanced budget goal of 2004, to which the Jospin Government had agreed. Therefore - and this has to be the most significant irony of the electoral campaign - Jospin and the Socialists found themselves - uncomfortably — in the completely reverse position from where it had been in the Spring of 1997: defending the constraining rules of EMU and the Stability Pact which it had previously attacked in its campaign for a 'euro social'. ${ }^{9}$ Thus, while the 1995 presidential and 1997 legislative elections centred very much around economic matters and the EMU constraint, this constraint proved something of an embarrassment for the presidential candidates and their parties, and they chose to largely steer 
clear of the matter. At a superficial level, Chirac's supporters emphasised Jospin's core socialist values which posed a danger to the competitivity of French business and thus economic growth. Chirac denounced the 'insidious statism of the government'. ${ }^{10}$ He argued that the Socialists were stuck in the past, adhering to a model abandoned by most European social democrats. In the meantime, Jospin's supporters accused Chirac of making promises he could not fulfil (especially on tax cuts).

\section{$\operatorname{Tax}$}

Tax cuts were the most important economic policy reform on offer from Chirac and the Raffarin Interim Government. Based on the over-optimistic forecast of 3 per cent economic growth (and the 1.8 per cent deficit for 2002 predicted - also over-optimistically - by Laurent Fabius), Chirac promised that a future UMP government would bring about cuts in income taxes by $a$ third over the life of the parliament (2002 to 2007) starting with an immediate cut of 5 per cent in 2002; would lower corporate taxes to the EU average during the same period; and would cut VAT payments for specific sectors, notably hotels, restaurants and catering. Chirac and the UMP targeted the French middle classes with these cuts (only the 17 million wealthiest of the 32 million households in France pay income tax). For 
poorer households, Chirac offered only a cut of 2 billion off the total collected from the residential tax. Francis Mer, the UMP interim government finance minister, sought to prove to a sceptical French public that the government would find the means to bring about these cuts. Mer wanted to demonstrate prior to the elections that Chirac would respect his election promises - unlike his failure to do so in 1995. Closer to the legislative elections, in June, Mer argued for the lowering of VAT on the hotel and restaurant sector (just as VAT had previously been lowered on domestic work) in an open letter to Frits Bolkestein, the European Commissioner responsible for fiscal policy. Mer recognised that this was a EU matter that could only be achieved at the EU level but he sought to initiate the decision making process to demonstrate the government's commitment on this matter. ${ }^{11}$ A few days earlier, one of the interim government's finance ministers, Jean-Jacques Aillagon, argued for the lowering of VAT on CDs! Obviously, the right targeted business and the middle class which would decrease government revenues by a total of $€ 30$ billion ( $£ 20$ billion).

Jospin and the Socialists challenged Chirac and the UMP, calling their tax cutting plans unworkable, especially given the spending constraints imposed by the Stability Pact (see below). However, the total proposed cuts 
by Jospin — amounting to 18 billion euro, albeit incorporating 4.28 billion in cuts set for 2003 already announced by the government in the Fabius Plan - might also have been called unworkable, based as they were on excessively high growth forecasts. However, Jospin and the Socialists claimed themselves to be more responsible than Chirac and the UMP in that the additional cuts in taxes by a future Socialist-led government would only take place from 2004, to allow the government to respect its European deficit cutting commitments. Jospin resisted the pressures from the 'socialliberal' wing within the party (led by Laurent Fabius) to promise greater tax cuts for the middle classes. Jospin called for tax decreases that would 'reconcile the middle classes and lower classes' ${ }^{12}$ brought about by a 5 billion euro break for those who paid income tax while the break would be designed to benefit poorer taxpayers considerably more than the wealthier ones) and providing 5 billion for those who did not pay tax through an increase in the 'prime pour l'emploi (PPE). Created in 2001, the PPE is a tax credit granted to the poorest workers (paid between .3 and 1.4 times the SMIC). Its beneficiaries — some 8.5 million workers — are for the most part (70 per cent) exonerated from paying tax. Jospin emphasised economic and political balance, understanding well the great reticence of the majority within his own party with regard to the lowering of income tax. Jospin also promised 
to diminish by half the residential tax which he considered 'the most archaic and unjust tax' by a total amount of 4.3 billion euros (more than twice the cut offered by Chirac). For the remainder of the presidential pack, the rightwing candidates uniformly called for income and corporate tax cuts, while left-wing candidates insisted upon at least the maintenance of existing tax rates and in most cases a steeper progression in income tax.

Other tax issues were the subject of less important partisan debate. On capital gains tax - high in France in comparison to other EU member states — candidates of the right predictably recommended a drop. Chirac argued that the Plural Left had increased this tax excessively, that it needed to be lowered sensitively to encourage investment in the more productive sectors of the economy. Bayrou called for the tax to be lowered but in the context of a harmonisation with the other EU member states. Addressing the small and medium sized businessmen of France, Le Pen called for a more progressive capital gains tax. Madelin proposed the complete elimination of the tax. Candidates on the left (Chevènement, Hue, Besancenot, Laguiller) generally favoured the maintenance of the tax at at least current levels, arguing that gains on capital should not be treated more favourably than gains on work. Chevènement recommended a Tax Schengenland to maintain higher taxes in parts of the EU wanting to maintain them. Mamère 
and the Greens took a relatively unique line on taxes with a considerable decrease in their total number and simplification to decrease the cost of tax collection and tax evasion, while insisting upon tax relief on investments in eco-friendly economic developments.

France's wealth tax (Impôt sur la fortune (ISF)) has excited debate that far exceeds its significance in terms of revenue collected for the government (approximately 1 per cent but more than doubling in total value from 1990 to 2001). It is a symbolically important tax. Most of the Left except the Greens which sought to do away with the ISF for reasons of simplicity in the tax regime - did not envisage to reduce it (at least officially). The Far Left sought to increase it dramatically, especially for the wealthiest. Fabius had tried to convince Jospin to lower it to prevent capital flight, at the risk of sparking opposition within the Plural Left Government. However, Jospin suppressed a report on the matter submitted by the Fabiusien deputy, Michel Charzat on 12 July 2001. Jospin steered clear of the matter during the election campaign, while other candidates of the Left argued in favour of its expansion, and Chevènement its application to works of art (Chevènement thus being the only candidate to adopt the specific recommendation of the Council of Taxes). Most of the Right - Bayrou, Madelin, Le Pen — sought to reform the tax significantly on the grounds 
that it encouraged capital flight and the departure of companies. Chirac, however, was vague on the matter. ${ }^{13}$

\section{Government spending — and abiding by the EU Stability and Growth}

\section{Pact}

At the 16 March European Council summit, President Chirac and Prime Minister Jospin confirmed France's commitment to bring public finances 'close to balance or in surplus' by 2004. In the domestic political debate, Chirac qualified his commitment to this goal given his promises on tax cuts but also, it might be suspected, to demonstrate traditional Gaullist disdain for any external (European) constraint on domestic policy. Furthermore, Chirac was wary of the experience of the mid-1990s when the Juppé Government was forced to increase VAT by 2 points to satisfy the Maastricht criteria, a move that contributed to the Right's defeat in the 1997 legislative elections. Chirac indicated on several occasions that France's pledge to her European partners and the Commission to balance the budget by 2004 would have to be put back to 2007 to allow for his spending plans. In direct contradiction to Chirac's commitment of 16 March. Chirac's camp calculated that his programmes and increased pension costs would increase state spending by $€ 35$ billion. However, his opponents argued that it would 
cost a great deal more $\left(€ 56 \mathrm{bn}(£ 34.5 \mathrm{bn}){ }^{14}\right.$ The European Commission in the meantime predicted a French deficit of 1.9 for $2002 .{ }^{15}$ In the lead-up to the legislative elections, at the 4 June Eurogroup meeting of Euro-zone finance ministers, Francis Mer sought to persuade his Euro-zone counterparts to postpone debate on national economic policy guidelines until after the French elections. ${ }^{16}$ As with Chirac, Mer made careful use of language:

C'est l'objectif qui compte (celui de l'assainissement budgétaire), ce n'est pas tel ou tel chiffre précis, tel ou tel pourcentage. Ne nous accrochons pas à une date symbole. ... Il faudra qu'avec quelques autres pays on essaye de trouver un langage commun ..., quitte à le faire dans des termes qui permettent d'assurer le maintien du cap sans forcément être obligé de respecter à la lettre quelque chose qui a toujours été exprimé en termes de principe. $^{17}$

Nonetheless, Mer maintained France's commitment to respecting the date:

Si l'on veut, l'on peut. C'est une question de choix, c'est une question de décisions, c'est une question de volonté. Tout est possible à condition de ne 
pas casser la baraque, c'est-à-dire de ne pas casser une dynamique de croissance. $^{18}$

Raffarin and Mer would not have appreciated the public declarations of the German Finance Minister, Hans Eichel, who assured that he would not raise 'le petit doigt' to help France in its spending path. ${ }^{19}$

Like Chirac's calculations, Jospin's policies assumed, over optimistically, that economic growth would reach an average of 3 per cent over the following five years. Jospin insisted on sticking to the 2004 schedule to balance the public budget, while claiming that public spending would rise on average 1.5 per cent a year. To have any chance at success in balancing the budget, Jospin would have had to consecrate the entirety of his margin of manoeuvre created by economic growth from 2002 to 2004 to lowering the public spending deficit. Only after that date would he begin to put into effect his tax cutting plan. Jospin presented himself as the responsible candidate, who might be tying the governments hand, but only doing so temporarily.

As for the other candidates, most of those on the Left and Right refused to commit France to the European constraint. The pro-European Bayrou called for France to respect the goals of the Stability Pact. However, 
Bayrou certainly did not publicly embrace the policy views of two former UDF finance ministers (Jean Arthuis and Edmond Alphandery) who had advocated, when in opposition, a balanced budget requirement on current expenditure and the extension of parliamentary control over aspects of the budget (to check supplementary expenditure by the government). ${ }^{20}$ This was not a policy position raised in the presidential or legislative election campaign.

\section{The 35 hour week and employment policy}

Even with the substantial drop in unemployment over the previous five years, interventionist employment creation measures remained a rallying cry for the left-wing candidates in the presidential and legislative elections. While the right tended to steer clear of such interventionism - with Madelin and Le Pen deriding it - some interventionist measures were also advocated by right-wing candidates. Chirac promised to prolong the emplois-jeunes posts created under the Plural Left Government. Lionel Jospin and the Socialist Party emphasised the need for additional measures to stimulate job creation, spending extra government revenues on improved job training schemes, 900,000 new jobs pledged through to 2007 , including 200,000 for unemployed workers over 50 (contrats de retour à l'emploi). 
Most of the presidential candidates and parties accepted the continuation of the 35 hour week. Some of those on the Left defended it although Chevènement called for the softening of its application with the hours worked beyond 35 remunerated at a higher rate. Having attacked the policy since its creation as an economically non-sensical measure, most of the candidates of the Right, including Chirac, called for a relaxed application of the policy, recognising that a full elimination of the policy would be problematic. Only Madelin and Le Pen called for the complete elimination of the 35 hour week policy — with a return to at the very least, the previous 39 hour week.

A few of the right-wing presidential candidates (including Bayrou) also continued with the traditional offer of a reduction of social charges imposed on companies that hired additional staff. Chirac offered a relief in the payment of social charges amounting to 6 billion euro, targeted specifically at workers on lower salaries and younger workers with less than two years of post-secondary study. Left-wing candidates, including Jospin, did not pursue this policy line which many considered to have been exhausted as an effective mechanism to reduce employment.

Serge July for his part asked about the role of the 35 week policy in Jospin's defeat of 21 April, ${ }^{21}$ given the importance of this policy as 
'emblematic' of the Left. July argued that the policy worked to the advantage only of white collar managerial staff, the majority of which increased their salaries in 2001 while profiting from the reduction in total working time. Workers in those big companies where trade unions were in a position of relative strength also profited. The majority of workers, however, suffered: those in the civil service - where strikes had been widespread - those in the hospital sector, but most of all those working in small and medium sized companies (petites et moyennes entreprises, PME) who were hit hard by the annualisation of the 35 hour week allowed under the law, salary freezes and a drastic limitation of supplementary hours. The 35 hour week thus contributed to social divisions rather than reducing them and, according to July, greatly eroded the trust of a large section of moderate left-wing voters in Jospin and the Socialist-led government.

The rigidities of the French labour market are normally signalled out by Anglo-American observers as one of the major causes of high levels of structural unemployment in the country - along with the relatively high minimum wage. In the 2002 campaigns, only the Thatcherite candidate Alain Madelin dared to call for the liberalisation of the French labour market. The matter gained some electoral significance following the 14 January ruling of the Constitutional Council against article 107 of the 
Government's law of social modernisation ('loi de modernisation sociale') adopted in parliament on 19 December 2001. Robert Hue and the PCF coalition partners insisted upon this article as a vital protection for staff against 'ruthless' firings, after the massive lay-offs by $M \& S$ and Danone over the previous two years. The article redefined the field of application of 'licensiement économique' (mass firing for economic reasons) only authorising such redundancies in three cases: when 'all other means have been exhausted to overcome serious economic difficulties', when 'technological change puts at risk the survival of the company', and in the case of 'necessities of indispensable reorganisation to ensure the survival of the company' (author's translation). The PS leadership almost certainly allowed the inclusion of article 107 as a political gesture to the PCF, while predicting that the Constitutional Council would find this to be unconstitutional. Fabius stated publicly that article 107 was fundamentally problematic for investment and employment but its inclusion was necessary for political reasons to mollify the PCF anxious to demonstrate its left-wing credentials to its increasingly disillusioned electorate. On 26 October 2001, fifty-six directors of the biggest French companies had called on the government to reject article 107 (including those directors with strong links to the Socialist Party) which further promised to transform the issue into a 
battle cry for the PCF and other left-wing parties anxious to distance themselves from the Socialists in the upcoming election campaigns. The Constitutional Council found the article to be contrary to freedom of enterprise and inherently dangerous to the competitiveness of the company so that its existence would be menaced. Both Hue and Mamère announced their outrage at the Council's decision, deemed 'reactionary' and 'a provocation', with Hue accusing the Council of 'espousing the ultraliberal theses of the Right and the MEDEF' and demanding that the Government submit a new text - which it did not. ${ }^{22}$ Hue, Mamère and the candidates of the Far Left campaigned on this matter, Hue calling for an amendment of the French constitution if necessary.

Raising the minimum wage (the SMIC) has long been a component of many election campaign platforms by right and left-wing candidates and parties. In 2002, the candidates of the right entirely resisted the temptation to promise an increase in the SMIC. In a 1 June interview with the newspaper Ouest France, Raffarin argued that an increase of SMIC would only be considered with a full review of the consequences of this action on the economic situation and above all on employment, with a decision to be taken during the third week of June after consultations with the social partners, ${ }^{23}$ which effectively was another way of discounting any probability 
of an increase. In the run-up to the legislative elections, quite late in the campaign, the Socialists resorted to the SMIC weapon: promising that the minimum wage would be increased 5 per cent if the Left was to win the elections. The Socialists emphasised how this increase would add to the already considerable benefit created by the increase in the PPE and the drop in the tax rate imposed on lower salaried workers. Presidential candidates further to the left promised at least as much. Chevènement and the PR promised a 25 per cent increase in the minimum wage over a period of five years!

\section{Pensions reform}

With an ageing population, the future provision of pensions has been one of the most pressing economic issues facing France (like most West European countries). It is a particularly sensitive policy area for any government as reform suggests a decreased take home salary, undermines the 'solidarity' principle of the existing 'répartition' system and even potentially involves the rise in the retirement age. In 1991, Michel Rocard noted that pension reform was capable of destroying five or six governments which would have to deal with it. However, the last significant reform to pensions was in 1993, when the Balladur Government increased the number of contribution 
years in the private sector from 37.5 to 40 years. The efforts of the Juppé Government to bring about further reform - notably in the public sector were blocked by the protests of late 1995. The development of private pensions funds - in addition to the existing mandatory contribution system of 'répartition' - has become a major battleground in party political debate: the further to the left the more opposed to the encouragement of any private system through tax relief. Pensions, for most of the mainstream presidential candidates, was a pressing issue which they claimed would be a priority of their quinquennat. On 12 February 2002, the EU Council of Ministers entered into the fray by issuing a statement announcing that it was indispensable for France to reform its pension system, especially given that pension funds did not appear in the government budget and thus a shortfall — set to increase as a larger proportion of the population entered retirement — was effectively a hidden contribution to the public deficit. Both Jospin and Chirac accepted the need to provide tax relief to encourage people to save for their retirement. However, both candidates - in particular Jospin - had to maintain great caution on the matter, defending the existing system of 'répartition' as the main system for the provision of pensions. The idea of capitalisation had progressed on the Centre-Left — promoted by the 'social-liberal' modernisers — but there remained significant differences 
with the Right. In the 1995 presidential debate, Chirac defended a complementary regime encouraging private pensions savings. Jospin however stated that he opposed a pension fund system, because this was not mutualiste and thus escaped the control of the social partners and it amounted to the introduction, despite Chirac's rhetoric, of a system of private insurance. In 1997, the Juppé Government adopted a 'proposition de loi instaurant les fonds de pension', the Thomas law (named after the UDF deputy, Jean-Pierre Thomas). But the victory of the Plural Left in the legislative elections brought an end to this reform. The decrees of the Thomas law were never published and the law was abrogated in 2001. However, over the life of the Jospin Government, the Socialists modified their position on the matter. In a December 1997 interview in Les Echos, Jospin declared that 'the government is not hostile to measures favouring savings for retirement'. ${ }^{24} \mathrm{He}$ even added: 'No one challenges the idea that private sector workers can dispose of "sur-complementary" retirement regimes, that is to say pension funds' (provocatively using the term so despised on the Left). The Jospin Government did not remain totally inert on the matter. In 1999, the Government created a fund which was to be used to compensate for part of the shortfall in the existing pension schemes (the Fonds de réserve des retraites, which consisted of 12 billion by the end of 
2002 , to rise to 152 billion by 2020). To involve the social partners in preparing the terrain for a future, more significant reform, Jospin created the permanent Comité d'orientation des retraites (COR) in the spring of 2000, chaired by Yannick Moreau, which submitted a report to the Prime Minister in December 2001, with the aim of outlining the existing situation. Despite the boycott of the MEDEF, the COR made progress and was set to take on the issue of capitalisation in September 2002. Jospin's own Conseil d'Analyse Economique (a body of economic advisors attached to Matignon) examined the matter as did a group led by Bernard Quintreau, which presented its report on 14 March 2002. Despite these reports and various recommendations, Jospin himself was highly cautious on the matter of pensions during the presidential election campaign. The other development in government policy came from Bercy. The Fabius Law, adopted in February 2001, installed, the 'plan partenarial d'épargne salariale volontaire' (PPESV). This law permitted salaried employees in the private sector to build up savings over 10 years or longer. Officially, it was not a pension fund, but the savings formula, long in duration and voluntary, very much resembled a pension fund. Trade Union opposition to the introduction of complementary private plans was also gradually eroded and four unions (CGT, CFDT, CFTC and CGC) created at the start of 2002, a 'comité 
intersyndical pour l'épargne salariale', demonstrating that they were no longer hostile to cautious pension reform. Only Force Ouvrière maintained its opposition to any new pensions saving regime which was seen as an attempt by the government to gradually supplement the payments from the 'répartition' system with private savings.

During the 2002 presidential election campaign, most of the candidates were rather vague on the details of how they would set about reforming pensions. Public scepticism with regard to private schemes had been intensified by the Enron scandal in the US. Jospin defended the existing system but opened the possibility of the further encouragement of complementary regimes, while officially opposing the creation of 'private' pension regimes. Jospin promised, as the first major action of a new Socialist-led Government, the organisation of a conference with the social partners to discuss the matter. Chirac was somewhat braver on pensions, defending the French system of 'répartition' and existing complementary state funds, he also called for 'fonds de pension à la française': a third stage of retirement fund, based on capitalisation. Chirac hit out against Jospin regularly on the pensions matter, claiming that the Plural Left Government had done nothing to reform the existing system or address the looming pensions crisis. Some other candidates on the Right - Bayrou and Madelin 
— were even more direct in their support for the encouragement of private pensions, pointing out the irony that only civil servants currently benefited from a special fiscal regime designed to encourage them to save for their retirement. Only Le Pen and Megret hit on the demographic element of the problem, calling for greater government assistance to raise the birth rate. Unsurprisingly, most candidates of the left defended the existing system and opposed the development of private pensions savings schemes. However, Mamère and the Greens accepted the need to keep existing voluntary contribution regimes but also to examine future voluntary mechanisms but only in tight consultation with the social partners with a clear focus on the impact upon the 'répartition' system. All the candidates maintained a similar line on the need to involve the social partners actively in any future pension reform.

\section{The remaining confetti of the former state owned empire}

Nationalisation, privatisation or the invitation of private sector capital to fund publicly owned companies had long been major issues of contention during presidential and legislative elections. With most former publicly owned companies and banks privatised or progressively opened to private sector capital during the 1980s and 1990, this issue was no longer in the 
ideologically charged realm that it had previously been. Most of the Left accepted that renationalisation was not an option. However, the need to defend public utilities against their dismantling by European competition policies and EU governments anxious to gain access to the French market had long been a matter of consensus between the Left and much of the Right, with even the relatively liberal Balladur Government making a vigorous defence of the maintenance of French public utility monopolies in debates with the European partners. However, governments of both the left and right were tempted into attracting private sector capital for these utilities in order to cover their massive investment needs without contributing the public sector deficit. In 2002, most of the candidates of the Left continued to make a spirited defence of the two big remaining public utilities Electricité de France (EDF) and Gaz de France (GDF). Chevènement, Hue, Mamère and others argued that France must insist upon a derogatory clause at the EU level to maintain its remaining publicly owned services on grounds of social justice: the provision of gas and electricity not to be subject to market forces and thus potential price rises which would hit lower income households disproportionately. Left-wing candidates allied themselves with the trade unions which were for the most part adamantly opposed to the capitalisation of the two companies and the workers' loss of 
their protective civil servant status. Socialist policy, however, had shifted over the previous five years. Jospin - aware of the massive investment needs of these companies - embraced the 'social-liberal' policy advocated by Fabius, calling for the capitalisation of these two companies while retaining for the state the majority share. It is likely that the social-liberals in the government wanted to go further toward full privatisation but political niceties and the threat of an inevitable trade union backlash prevented them from calling for this. Policy positions on the Centre-Right had similarly shifted. Chirac and Bayrou called for these public utilities to be opened to capitalisation while still insisting upon the state as majority shareholder.

\section{A failure to spell out a coherent economic vision of the future}

Only the candidates and parties of the Extreme Left and the liberal Madelin might be considered to have presented a coherent overall vision of the desirable development of France's economy. The overall economic policy direction of the Socialists remained in flux with substantial differences within the party on nearly all major economic matters of the day. Jospin's presidential programme was prepared by members of the 'modernising' wing of the Socialist party (Alain Bergougnioux, Vincent Peillon, Marisol Touraine, Pierre Moscovici, Alain Richard and Gilles Finchelstein) linked to 
either the Jospin-Rocardian club Socialisme et Démocratie or the 'socialliberal' think tank, the Jean Jaurès Foundation, and the ideas of StraussKahn and Fabius, the 'modernisers' who continued in their attempt to pull the party in a 'social-liberal' direction. At the same time, Jospin consulted the fourteen heavyweights of the Socialist Party on his platform as a diplomatic exercise to diminish potential conflict within the party. Jospin's own document appeared to eclipse that of the PS prepared by the more leftwing Martin Aubry. In January, the former and current finance ministers published their own policy statements: Strauss-Kahn's La Flamme et la Cendre was a four hundred page essay on socialism in the Twenty-first century, France, European and globalisation; ${ }^{25}$ while Fabius' 'Laurent Fabius 2002-2007: les chantiers de la Gauche moderne' (published by the Jean Jaurès Foundation) focused on the needed policies for the next 5 years. ${ }^{26}$ Fabius praised Jospin and the record of the government - while ignoring the difficulties of the 35 hour week policy — but also recognised the difficulties facing the French economy and need to reinforce the relations among the social partners to bring about further reform. Fabius also directly challenged the political constraints created by the Plural Left alliance, encouraging Jospin not to make promises that could not be kept or delay future reforms so to avoid upsetting coalition partners. Fabius outlined a 
series of reforms that he hoped Jospin would agree with: pension reform, with increased years of contributions in the public sector, the encouragement of voluntary savings for retirement to complement existing schemes, the partial and sensible replacement of retiring civil servants and the 'evolution' of the status of the two public utilities, GDF and EDF, with the state remaining the majority share-holder. Many of these policy proposals were taken up by Jospin in his own campaign platform, Je m'engage, presented to the public two months later on 18 March - albeit within the context of Jospin's own 'modern socialism' versions of the 'Third Way' (a term with which he refused to be associated).

Chirac's own policy positions were drawn up by a cabal of his advisers at the Elysée with a small number of loyalists in the RPR, without any broad consultation in his party. However, Chirac's own positioning on economic policy demonstrated a certain schizophrenia: on the one hand he advocated cautiously liberalising economic policies, while at the same time he refused to be associated with the term liberal, distancing himself markedly from Alain Madelin but also certain close allies within the RPR notably Nicholas Sarkozy — widely associated with the liberal right. Chirac mixed free market ideas alongside state interventionism, while leaning rhetorically in favour of the former. He placed emphasis upon 
individual initiative, work and merit rather than state assistance. He sought to lower taxes and charges on companies with simplification of administrative procedures with the aim of creating a million companies in one year. ${ }^{27}$ Playing traditional Gaullist cards, Chirac resisted the European constraint and promised more spending on law and order and defence (notably with the construction of a second French aircraft carrier).

Thoughtful discussion on the necessary development of the appropriate role of the State in the economy — views on which would shape policies on most specific aspects on economic policy discussed above was virtually absent during the presidential and legislative campaigns. One leading French philosopher, Alain Touraine spelled out the nature of the issue in a Le Monde article published a few weeks prior to the first round of the presidential elections. ${ }^{28}$ In his article, Touraine argued that the major issue dividing the candidates was how to reconcile the maintenance of a part of public institutions (in particular social security) with the greater acceptance of the laws of the market and the determination of which modes of State intervention to be rejected and which to be proposed. On this issue there are three possible positions: to defend the ancient forms of intervention of the State; or to adopt a liberalism that limits the most possible the role of the State; to refuse both the old administered economy and extreme 
liberalism and to search out new forms of useful State intervention. Touraine challenged the first two positions as highly problematic. The defence of the 'public sector' in the name of the 'public service' corresponds to the interest of numerous people (especially those working in the public sector) but maintaining the current role of the State simply to defend the interests of those working in it is obviously wrong. Liberalism was simply not possible politically: any candidate proposing the dismantling of social security would be immediately eliminated.

Touraine argued in favour of examining 'new forms of State intervention' with three core principles in mind. First, intervention must diminish inequality. Second, the social objectives and economic goals of the State must recognise that the more a society is advanced the more noneconomic factors of economic growth are important (as recognised by most economists, a leading example being Robert Solow). To Touraine, the increasingly central economic issue for France in the years to come is education, since the level of education will determine the quantity and quality of choices offered to individuals. Third, there exists no necessary reason for the State to manage all public goods. Many European countries combine different forms of management more effectively than France: private, associative, cooperative, local and state. Many French universities 
(officially public institutions) managed themselves already with an almost totally autonomous control over their resources. This third principle is supported by the public's demand for further decentralisation.

Where must the state continue to intervene? What are the domains of collective and individual life that must be managed by the market? What are the new priorities to assign to government intervention? It is particularly difficult to combine in a coherent and realistic manner answers to these questions. None of the presidential candidates succeeded in doing so and Chirac and Jospin were particularly obfuscatory, focusing instead on politically sensitive tinkering. The former's complaints of embedded ‘socialism' in France and the latter's defence of a 'modern socialism' against the ravages of global capitalism amounted to little more than vague rhetoric.

\section{References and Notes}

${ }^{1}$ See D. Howarth, 'The French State in the Euro-Zone: "Modernisation" and Legitimizing Dirigisme", in K. Dyson, ed., European States and the Euro, Oxford: OUP, 2000, 14572; B. Clift, The Political Economy of the Jospin Government' in Modern and Contemporary France, special edition on the Jospin Government, Summer, 2002; G. Desportes \& L. Mauduit, La Gauche Imaginaire et le nouveau capitalisme. Paris: Grasset; M. Marian, 'Lionel Jospin, le socialisme et la réforme', Esprit, March-April, 
1999, pp. 112-121; J.-C. Cambadélis, L'avenir de la gauche plurielle. Paris: Plon, 1999; B. Victor, Le Matignon de Jospin, Paris: Flammarion, 1999. For the government's own presentation of its policies see Ministère de l'Economie des Finances et de l'Industrie, Politique économique, rapport économique, social et financier du Gouvernement. Paris: Economica, several years. For the OECD's account see OECD, Country survey, France. Paris: OECD, several years and for a more critical year-on-year account see Economist Intelligence Unit, Country Report, France, London: EIU, several years.

2 J. Arthuis, Dans les coulisses de Bercy, le cinquième pouvoir, Paris: Albin Michel, 1998.

${ }^{3}$ G. Desportes \& L. Mauduit, La Gauche Imaginaire et le nouveau capitalisme. Paris: Grasset, 1999.

${ }^{4}$ Total taxes reached 44.8 per cent in 1996, 45 in 1997, 44.8 in 1998, 45.5 in 1999 and 45.1 in 2000.

5 L. Jospin, Le Socialisme modern, Paris: Fondation Jean Jaurès, 1999 / Modern Socialism. London: Fabian Society, 1999.

${ }^{6}$ The Robien law of December 1996 enabled the state to pay, entirely for a certain period and partially for an additional period, the social charges of companies which diminished weekly working hours and employed more workers. This had a positive but limited effect on unemployment.

${ }^{7}$ L Jospin, op. cit., 1999.

${ }^{8}$ E. Aeschimann \& P. Riché, La guerre de sept ans: histoire secrète du franc fort, 1989 1996. Paris: Calmann-Lévy, 1996. 
${ }^{9}$ In the 1997 election campaign, the Plural Left called for a 'euro social' which consisted of: rejecting the Stability Pact (agreed by the Juppé Government in December 1996); insisting upon a more interventionist political counterweight to the European Central Bank; the devaluation of European currencies in relation to the dollar; the entry of Italy into Stage Three of EMU. The Plural Left also insisted upon an end to national budget cuts and the creation of an activist EU Employment policy via the inclusion of the Employment Chapter in the Amsterdam Treaty (which had been previously rejected by the Major and Kohl governments). See Howarth, op. cit., 2000 and P. Pochet, 'The Social Consequences of EMU: An Overview of National Debates', in P. Pochet \& B. Vanhercke, eds., Social Challenges of Economic and Monetary Union. Brussels: European Interuniversity Press, 1998, pp. 67-102.

${ }^{10}$ Le Monde, 27 March 2002.

${ }^{11}$ Le Monde, 5 June 2004.

${ }^{12}$ Le Monde, 9 April 2002.

${ }^{13}$ On the ISF, Chirac noted: 'Je suis d'accord avec le Conseil des impots, qui indique que la fiscalité du patrimoine de France doit être revue dans le sens de plus de justice et une meilleure adaptation de la fiscalité aux diverses situations des personnes et en ayant également à l'esprit la nécessité d'éviter l'expatriation des capitaux et des forces vives de notre économie' (Le Monde, 17/18 March 2002).

${ }^{14}$ Financial Times, 22 March 2002.

${ }^{15}$ It can be noted that the actual French deficit for 2002 according to the government's own figures exceeded the 3 per cent figure (Le Monde, 25 February 2003). 
16 Le Monde, 5 June 2002. The European Commission has made the interim government's campaigning more difficult. On 4 June, the European Commission issued a blunt warning that the credibility of the euro was at stake due to threats of delays in certain member states to balancing budgets. Mer's case was not strengthened by the other member states. The new Portuguese government (elected in March on the promise of a lowering of corporate and income taxes) reaffirmed that it would respect the 2004 date even if this meant a necessary increase in taxes (the Italians and Germans also made this commitment!) (Libération, 5 June 2002).

${ }^{17}$ Libération, 5 June 2002. 'It is the objective that counts [a low budget deficit], it is not such or such precise figure, such or such percentage. We must not attach ourselves to a symbolic date.... It is necessary that with the other countries we find a common wording ... even if this is in terms that permit us to achieve the general objective without forcibly being obliged to respect to the letter what has always been expressed in terms of principle.' (author's translation).

${ }^{18}$ Ibid. 'If we want to, we can. It is a matter of choice, it is a matter of decisions, it is a matter of will. Everything is possible on condition that we do not 'casser la baraque', that is we do not break a dynamic of economic growth' (author's translation).

${ }^{19}$ Le Monde, 27 May 2002.

${ }^{20}$ J. Arthuis, op. cit., 1998; E. Alphandéry, La réforme obligée sous le soleil de l'Euro, Paris: Grasset, 2000.

${ }^{21}$ Libération, 24 May 2002.

${ }^{22}$ Le Monde, 15 January 2002.

${ }^{23}$ Libération, 3 June 2002. 
${ }^{24}$ Les Echos, 9 December 1997

${ }^{25}$ Dominique Strauss-Kahn, La Flamme et la Cendre, Paris: Grasset, 2002.

${ }^{26}$ Laurent Fabius, 'Laurent Fabius 2002-2007: les chantiers de la Gauche moderne', Jean Jaurès Foundation, January 2002.

27 'Ils ont dit', Le Monde, 3 April 2002.

${ }^{28}$ Le Monde, 2 April 2002. 